Acta Technologica Agriculturae 3

Nitra, Slovaca Universitas Agriculturae Nitriae, 2015, pp. 83-87

\title{
POTENTIAL TO INCREASE PRODUCTIVITY AND SUSTAINABILITY IN ARGENTINEAN AGRICULTURE WITH CONTROLLED TRAFFIC FARMING: A SHORT DISCUSSION
}

\author{
Diogenes L. ANTILLE*1, Silvia C. IMHOFF², Carlos A. ALESSO², \\ William C. T. CHAMEN ${ }^{3}$, Jeff N. TULLBERG ${ }^{1,4}$ \\ 'University of Southern Queensland, National Centre for Engineering in Agriculture, Toowoomba, QLD, Australia \\ ${ }^{2}$ Universidad Nacional del Litoral, Esperanza, Santa Fe, Argentina \\ ${ }^{3}$ CTF Europe Ltd., Maulden, Bedfordshire, United Kingdom \\ ${ }^{4}$ Australian Controlled Traffic Farming Association Inc., Buninyong, VIC, Australia
}

\begin{abstract}
Drivers for and potential barriers against adoption of controlled traffic farming (CTF) systems in Argentina are reviewed. Traffic compaction is one of the main factors affecting crop productivity within Argentinean agriculture, and has significant although less quantified impacts on the whole-of-farm system. This suggests that the benefits of no-tillage (NT), which represents the dominant form of cropping in Argentina, are not fully realised. Conservative estimates indicate that crop yields could be improved by at least $15 \%$ if NT is used in conjunction with CTF. Cost-benefit analyses of available options for compaction management are required. Despite this, and based on reported evidence internationally, a shift toward increased uptake of CTF within Argentinean agriculture is likely to: (1) improve productivity and farm profitability, (2) enhance environmental performance, and (3) maintain competitiveness of the agricultural sector. Appropriate technical advice and support is a key requirement to drive adoption of CTF. Therefore, the adoption process will benefit from collaboration developed with well-established research and extension organisations in Australia and the United Kingdom, and active engagement of machinery manufacturers.
\end{abstract}

Keywords: greenhouse gas emissions; no-tillage; random traffic; resource use efficiency; soil compaction; sustainable intensification

In Argentina, agriculture-related activities account for approximately $20 \%$ of the country's GDP and represent the sector with the greatest prospect for growth (Lence et al., 2010). Intensification of agriculture and increased output to support economic growth will necessitate rapid adoption of sustainable technologies, and their integration with those already in place. Estimates indicated that the area under no-tillage (NT) in Argentina is approximately 30 million ha representing $90 \%$ of the land used for grain cropping (SIIA, 2015). This area recorded a ten-fold increase between 1990 (3 million ha) and 2010 (SIIA, 2010) and is, to a large extent $(\geq 70 \%)$, continuously cropped using permanent NT (Friedrich et al., 2012). The main driver for widespread adoption of NT in Argentina has been the acknowledgement of multiplicative agronomic, economic and environmental benefits brought about by this technology, assisted by introduction of genetically modified crops, improved nutrient management practices, and effective research and extension effort (Manuel-Navarrete et al., 2009). National averages suggest an increase in productivity ( $\mathrm{kg}$ grain per ha) equivalent to approximately $60 \%, 30 \%$ and $20 \%$ for corn, wheat and soybeans between 1985-1995 and 1995-2014 (SIIA, 2015), respectively. Readers are referred to several studies dealing with global adoption of NT cropping, and associated effects on crop productivity and sustainability (e.g., Kassam et al., 2009). Despite this, concerns have been raised over the long-term sustainability of NT cropping associated with deterioration of the soil resource caused by traffic compaction. Several studies conducted in Argentina (e.g., Díaz-Zorita et al., 2002) have shown that in long-term NT systems subjected to frequent, non-organised traffic by agricultural vehicles soil compaction can be significant. This occurs despite the fact that these systems have relatively lower traffic intensities (by about 50\%) compared with conventionally-managed tillage systems (Kroulík et al., 2009; Mašek et al., 2014). Development of high-capacity agricultural machines has contributed to reduced costs, increased fuel efficiency and work rates (Kutzbach, 2000) but often at the expense of increased risk of soil compaction, and particularly subsoil compaction, due to high axle loads (Spoor et al., 2003; Bennett et al., 2015). The continuous increase in axle loads has, to some extent, offset advances made by the industry in developing improved running gear, such as in tyres and tracks technology, to reduce contact pressures (Misiewicz et al., 2015). This also means that subsoil stresses have continued to increase (Keller and Arvidsson, 2004). For example, work conducted by Chamen (2015), based on models of Koolen et al. (1992) and Keller et al. (2007), suggested a five-fold increase in machineryinduced subsoil stresses (depth: $0.4 \mathrm{~m}$ ) between 1980 and 2010 ( $\geq 30 \mathrm{t}$ combine harvesters). The effects of trafficinduced compaction are often persistent (e.g., more than 
five years), particularly in the subsoil (e.g., Logsdon et al., 1992; Radford et al., 2007). In intensively managed soils (e.g., double-cropping) under NT, these effects are exacerbated by the frequency of traffic, which therefore restricts the opportunities for soil repair through natural processes.

Remediation of compaction through tillage does not appear to be a practicable option for the majority of grain growers in Argentina. The shift towards NT farming observed during the 1990's meant that traditional tillage implements are not readily available. It is also known that alleviation of deep compaction is an energy-demanding process (Tullberg, 2000) and is transient (Chamen, 2011). The impact of soil compaction on crop productivity, the environment, and on the whole-of-farm system is well documented (e.g., Soane and van Ouwerkerk, 1995; Radford et al., 2001; Li et al., 2008; Chamen et al., 2015), which has implications for countries such as Argentina, whose economy relies to a large extent on commodity exports (FAOSTAT, 2015). Therefore, development of management strategies to avoid soil compaction, or to minimise the actual damage where it is unavoidable, is required. In this respect, controlled traffic farming (CTF) systems are regarded as a practical and cost-effective technology to minimise the impact of field traffic-induced soil compaction (Tullberg, 2010; Kingwell and Fuchsbichler, 2011; Chamen et al., 2015).

The Australian Controlled Traffic Farming Association Inc. (ACTFA, http://actfa.net/) defines CTF as a system in which: (1) all machinery has the same or modular working and track widths so that field traffic can be confined to the least possible area of permanent traffic lanes, (2) all machinery is capable of precise guidance along those permanent traffic lanes, and (3) the layout of the permanent traffic lanes is designed to optimise surface drainage and logistics. In welldesigned systems, permanent traffic lanes occupy less than $15 \%$ of cultivated field area. By contrast, in non-CTF systems varying equipment operating and track widths result in random traffic patterns, which can cover up to $85 \%$ of the cultivated field area each time a crop is produced (Kroulík et al., 2009). CTF is not only an engineering solution to some of the unwanted effects of soil compaction but importantly it transforms a problem of random traffic-induced soil compaction into an advantage of improved trafficability and timeliness, which has additional agronomic and environmental benefits (Tullberg, 2010; Gasso et al., 2013; Antille et al., 2015).

At present, global adoption of CTF appears to be small with the exception of Australia, where it is used by approximately $25 \%$ of grain growers (Tullberg et al., 2007; Chamen, 2015). CTF remains a novel concept for most farmers in Argentina and therefore current uptake of this technology is almost non-existent. This article discusses some of the main benefits associated with adoption of CTF, particularly when coupled with NT, and the implications for crop productivity, soil health and all dimensions of sustainability within Argentinean agriculture. Drivers for and obstacles against adoption of CTF, relevant to Argentina, are also reviewed based on the experience of Australia and the United Kingdom, and reported evidence available

Table 1 Benefits of CTF likely to drive adoption in Argentinean grain cropping systems

\begin{tabular}{|c|c|c|}
\hline Factor & Description & Reference \\
\hline $\begin{array}{l}\text { Timeliness and field } \\
\text { efficiency }\end{array}$ & $\begin{array}{l}\text { - improved field access for all field operations, particularly } \\
\text { planting, spraying and harvesting }\end{array}$ & $\begin{array}{l}\text { ACTFA }^{1} \text {, CTF Alberta }{ }^{2} \text {, CTF Europe Ltd. }{ }^{3}, \\
\text { Bochtis et al. (2010) }\end{array}$ \\
\hline Tractive efficiency & $\begin{array}{l}\text { - improved energy use efficiency due to reduced rolling } \\
\text { resistance and wheel-slip. Reduced fuel consumption and } \\
\text { draft in minimum tillage systems under CTF }\end{array}$ & Burt et al. (1994), Tullberg (2000) \\
\hline Fertiliser use efficiency & $\begin{array}{l}\text { - greater fertiliser recovery in crop (both grain and biomass } \\
\text { by up to } 20 \% \text { ), reduced nutrient loss in runoff or gaseous } \\
\text { evolution }\end{array}$ & $\begin{array}{l}\text { Alakukku and Elonen (1995), Lipiec and } \\
\text { Stępniewski (1995), Antille et al. (2015) }\end{array}$ \\
\hline $\begin{array}{l}\text { Runoff and soil } \\
\text { erosion, internal } \\
\text { drainage }\end{array}$ & $\begin{array}{l}\text { - improved soil porosity and structural conditions, hence, } \\
\text { hydraulic conductivity (by a factor of } 2 \text { ) and surface infiltration } \\
\text { (by a factor of 4), and water (rainfall and irrigation) use } \\
\text { efficiency }\end{array}$ & $\begin{array}{l}\text { Li et al. (2001, 2007), Tullberg et al. } \\
\text { (2001), McHugh et al. (2009) }\end{array}$ \\
\hline $\begin{array}{l}\text { Crop yield, reduced } \\
\text { in-field crop variability }\end{array}$ & $\begin{array}{l}\text { - improved crop yield (by } 15 \% \text { or greater) with potential to } \\
\text { increase soil C sequestration through greater crop residue } \\
\text { returned to soil }\end{array}$ & $\begin{array}{l}\text { Radford et al. (2001), Botta et al. (2007), } \\
\text { Tullberg et al. (2007), Neale (2011), Smith } \\
\text { et al. (2014) }\end{array}$ \\
\hline $\begin{array}{l}\text { Greenhouse gas } \\
\text { emissions }\end{array}$ & $\begin{array}{l}\text { - reduced potential for } \mathrm{N}_{2} \mathrm{O} \text { emissions (by } 20 \% \text { to } 50 \% \text { ) with } \\
\text { enhanced absorption of } \mathrm{CH}_{4}\end{array}$ & $\begin{array}{l}\text { Ruser et al. (2006), Tullberg et al. (2011), } \\
\text { Antille et al. (2015) }\end{array}$ \\
\hline Profitability & $\begin{array}{l}\text { - improved resource use efficiency translates into greater } \\
\text { economic return }\end{array}$ & $\begin{array}{l}\text { Chamen (2011), Kingwell and } \\
\text { Fuchsbichler (2011), Chamen et al. } \\
\text { (2015) }\end{array}$ \\
\hline $\begin{array}{l}\text { Compatibility with } \\
\text { NT and precision } \\
\text { agriculture } \\
\text { technologies }\end{array}$ & $\begin{array}{l}\text { - demonstrated synergism between NT (or minimum tillage) } \\
\text { and CTF. Compatibility with variable rate technology but this } \\
\text { should be preceded by CTF. There is a requirement for good } \\
\text { (overall) soil husbandry to ensure that the implementation of } \\
\text { these technologies can deliver tangible benefits }\end{array}$ & $\begin{array}{l}\text { Tullberg et al. (2007), Godwin (2015), } \\
\text { Smith et al. (2014), Antille et al. (2015) }\end{array}$ \\
\hline
\end{tabular}


Table 2 Potential obstacles against CTF adoption in Argentinean grain cropping systems

\begin{tabular}{|l||c|c|}
\hline \multicolumn{1}{|l||}{ Factor } & \multicolumn{1}{|c|}{ Description } & \multicolumn{1}{c|}{ Reference } \\
\hline \hline $\begin{array}{l}\text { Equipment } \\
\text { incompatibilities, } \\
\text { reliance on contractors }\end{array}$ & $\begin{array}{r}\text { - non-matching equipment between crops in the rotation (e.g., cutter- } \\
\text { bars or planters widths). Potential incompatibilities between owned } \\
\text { and contracted farm equipment (e.g., track gauge, operating widths or } \\
\text { both). Lack of qualified labour to modify farm machinery }\end{array}$ & $\begin{array}{c}\text { McPhee et al. (1995), } \\
\text { Chamen (2006), Isbister et al. } \\
\text { (2013) }\end{array}$ \\
\hline Land tenure system & - influences the motivation to change the system & The authors \\
\hline $\begin{array}{l}\text { Cost of conversion, size } \\
\text { of farming enterprise }\end{array}$ & $\begin{array}{l}\text { - difficulties in gaining access to credit, changes in interest rates and } \\
\text { price of commodities, and associated financial risks. Adverse effects of } \\
\text { climate on yield, such as lack of rainfall, potentially overcome by greater } \\
\text { cropping reliability. Loss of product warranty when equipment is made } \\
\text { CTF-compatible. Cost of guidance systems and accuracy }\end{array}$ & $\begin{array}{c}\text { Kingwell and Fuchsbichler } \\
(2011), \text { Blacwell et al. (2013), } \\
\text { Rataj et al. (2013) }\end{array}$ \\
\hline $\begin{array}{l}\text { Direction of field } \\
\text { operations, field } \\
\text { characteristics } \\
\text { (topography, size, shape) }\end{array}$ & $\begin{array}{l}\text { - orientation of field operations permanently restricted to parallel } \\
\text { directions but can be overcome with changes to implement design. } \\
\text { Potential interference of in-field infrastructure for soil erosion control } \\
\text { (e.g., contour banks) or surface drainage. Careful design of permanent } \\
\text { traffic lanes' layout is required }\end{array}$ & $\begin{array}{c}\text { Chamen (2006) with data } \\
\text { from Titmarsh et al. (2003); } \\
\text { McPhee et al. } \\
\text { (2013) }\end{array}$ \\
\hline
\end{tabular}

Source: Chamen, 2006

in the scientific literature. Readers are referred to reviews by Tullberg et al. (2007) and Chamen $(2006,2015)$ dealing specifically with these issues for Australia and Northern Europe, respectively.

\section{Adoption of Controlled Traffic Farming}

Based on work compiled by Chamen (2006) for the United Kingdom, Tables 1 and 2 quote aspects of CTF relevant to Argentinean grain farming systems. The benefits of CTF highlighted in Table 1 are likely to be key drivers for adoption within Argentina. The reader is also referred to work reported in Isbister et al. (2013), where practical aspects of CTF implementation are addressed in detail.

The study by Botta et al. (2007) on soybeans showed that a $60 \%$ reduction in traffic intensity at harvest from about $40 \mathrm{tkm} / \mathrm{ha}$ (random traffic) to $15 \mathrm{tkm} / \mathrm{ha}$ (controlled traffic) increased grain yield by approximately $30 \%$ on average after three years. The increment in yield with controlled traffic improved profit margins by about USD 130 per ha (price of grain: USD 0.17 per $\mathrm{kg}$ ). The change from random to controlled traffic reduced fuel consumption by about $35 \%$ (Botta et al., 2007). The controlled traffic system was achieved by maintaining chaser bins on the edge of the field. The results by Botta et al. (2007) reinforce the potential of CTF to improve the profitability of a major crop in Argentina such as soybeans. However, further work is required to validate these findings for a wider spectrum of soil conditions and cropping systems using 'true' CTF systems.

\section{Conclusions and Future Work}

A key requirement is to use the store of information available with emphasis on technology transfer and development, drawing from the well-established experience and knowledge base internationally. Applied on-farm research into CTF in Australia is of particular relevance to Argentina due to similar scales and labour unit to area ratios of farming enterprises. There are also similarities in terms of cropping, edapho-climatic conditions, and management practices, which make the CTF technology readily transferable. Likewise, there are opportunities for Argentinean technology such as NT (discs) and relay planters to be used by Australian farmers. However, work is needed to assess the practicalities, costs, drawbacks and deliverable benefits of CTF at local (national) level. Soil compaction impacts need to be quantified on the wider aspects of farm economics to aid decision-making. Well-developed decision support systems that incorporate the economics of managing soil compaction can facilitate the farm-scale analysis of available options, including conventional practice (non(TF), conversion to CTF, use of low ground pressure vehicle systems (e.g., Smith et al., 2014) and precision tillage. The relative advantages of CTF and low ground pressure vehicle systems are discussed in Godwin (2015) and Godwin et al. (2015) based on results derived from long-term tillage $\times$ traffic trials established at Harper Adams University (Shropshire, United Kingdom). These results are supportive of the use of no- or minimum tillage systems in conjunction with CTF and low ground pressure vehicle systems. These latter systems may be a cost-effective option to minimise soil compaction in situations where machine-related constraints impose a restriction to adoption of CTF. Removal of drainage and soil compaction constraints is a key requirement to ensure that the benefits associated with the use of these systems are realised (Godwin, 2015).

A three-year research project established at Universidad Nacional del Litoral (Esperanza, Argentina), and funded by CONICET (Consejo Nacional de Investigaciones Científicas y Técnicas, http://www.conicet.gov.ar/), is investigating the effects of fully controlling field traffic on crop yield, soil water dynamics and greenhouse gas emissions (Imhoff, 2015). This research aims to validate the benefits associated with this technology to stimulate a shift toward uptake of CTF in Argentina. Data derived from this project may be used to develop whole-farm economics models applicable to Argentinean farming systems.

In addition to the above, the following work needs to be prioritised:

1. Increase awareness of CTF and its adoption as a means of improving farm profitability, environmental sustainability, and maintaining the agricultural sector's competitiveness. 
2. Promote on-farm action-learning research activities to:

a) determine if the expected benefits can be delivered,

b) develop appropriate and cost-effective CTF systems that meet the requirements of broadacre farming systems in Argentina.

3. Disseminate the knowledge through farmer-oriented workshops.

4. Promote active engagement of machinery manufacturers (Tullberg, 2010).

5. Engage with policy-makers to incorporate CTF into the suite of technologies listed under current legislation promoting the adoption of soil conservation practices (e.g., Soil Conservation Act No. 22.428, SADS, 2015).

Knowledge transfer will require a group of research and extension specialists, and technical advisers who need to be trained at universities and research centres both national and international. Therefore, international collaboration needs to be developed, particularly with Australia and the United Kingdom, to engage in research and development activities, and assist the mentoring process by those with proven experience in the field. Agreements with research organisations overseas may facilitate academic exchange and development of technical expertise. At national level, mentoring may be achieved using the range of technology networks available, including independent and private organisations, government-funded research institutions and extension agencies, and farmers groups. These bodies need to be alerted to the synergism of NT and CTF, and encourage land managers to shift from a largely production-driven approach to farming to one that can also deliver long-term economic and environmental benefits.

\section{Abbreviations}

CTF (Controlled traffic farming), GDP (Gross domestic product), GHG (Greenhouse gases), NT (No-tillage)

\section{References}

ALAKUKKU, L. - ELONEN, P. 1995. Long-term effects of a single compaction by heavy field traffic on yield and nitrogen uptake of annual crops. In Soil and Tillage Research, vol. 36, no. 3-4, pp. 141-152.

ANTILLE, D. L. - CHAMEN, W. C. T. - TULLBERG, J. N. - LAL, R. 2015. The potential of controlled traffic farming to mitigate greenhouse gas emissions and enhance carbon sequestration in arable land: a critical review. In Transactions of the ASABE, vol. 58, no. 3, pp. 707-731.

BENNETT, J. MCL. - WOODHOUSE, N. P. - KELLER, T. - JENSEN, T. A. - ANTILLE, D. L. 2015. Advances in cotton harvesting technology: a review and implications for the John Deere round baler cotton picker. In Journal of Cotton Science, vol. 19, no. 2, pp. 225-249.

BLACKWELL, P. - HAGAN, J. - DAVIES, S. - RIETHMULLER, G. - BAKKER, D. - HALL, D. - KNIGHT, Q. - LEMON, J. - YOKWE, S. - ISBISTER, B. 2013. Pathways to more grain farming profit by controlled traffic farming in WA. 2013 WA Crop Updates. Barton, ACT, Australia : Grains Research and Development Corporation.

BOCHTIS, D. D. - SØRENSEN, C. G. - GREEN, O. - MOSHOU, D. OLESEN, J. 2010. Effect of controlled traffic on field efficiency. In Biosystems Engineering, vol. 106, no. 1, pp. 14-25.

BOTTA, G. F. - POZZOLO, O. - BOMBEN, M. - ROSATTO, H. - RIVERO, D. - RESSIA, M. - TOURN, M. - SOZA, E. - VAZQUEZ, J. 2007. Traffic alternatives for harvesting soybean (Glycine max L.): Effect on yields and soil under a direct sowing system. In Soil and Tillage Research, vol. 96, no. 1-2, pp. 145-154.

BURT, E. C. - REEVES, D. W. - RAPER, R. L. 1994. Energy utilization as affected by traffic in a conventional and conservation tillage system. In Transactions of the ASAE, vol. 37, no. 3, pp. 759-762.

CHAMEN, W. C. T. 2006. Controlled traffic farming: literature review and appraisal of potential use in the U.K. Home-Grown Cereals Authority Research Review N. 59. Kenilworth, U.K. : Agriculture and Horticulture Development Board.

CHAMEN, W. C. T. 2011. The effects of low and controlled traffic systems on soil physical properties, yields and the profitability of cereal crops on a range of soil types. Unpublished PhD Thesis. Cranfield, U.K. : Cranfield University.

CHAMEN, T. 2015. Controlled traffic farming - from worldwide research to adoption in Europe and its future prospects. In Acta Technologica Agriculturae, vol. 18, no. 3, pp. 64-73.

CHAMEN, W. C. T. - MOXEY, A. P. - TOWERS, W. - BALANA, B. HALLETT, P. D. 2015. Mitigating arable soil compaction: a review and analysis of available cost and benefit data. In Soil and Tillage Research, vol. 146, PA, pp. 10-25.

DÍAZ-ZORITA, M. - DUARTE, G. A. - GROVE, J. H. 2002. A review of notill systems and soil management for sustainable crop production in the subhumid and semiarid Pampas of Argentina. In Soil and Tillage Research, vol. 65, no. 1, pp. 1-18.

FAOSTAT. 2015. Country profile - Argentina: economic indicators. Retrieved from: http://faostat.fao.org/CountryProfiles/Country Profile/Direct.aspx?lang=en\&area=9. Accessed 01 July 2015.

FRIEDRICH, T. - DERPSCH, R. - KASSAM, A. 2012. Overview of the global spread of conservation agriculture. Field Actions Science Report, 6 (1 SPL).

GASSO, V. - SØRENSEN, C. A. G. - OUDSHOORN, F. W. - GREEN, O. 2013. Controlled traffic farming: a review of the environmental impacts. In European Journal of Agronomy, vol. 48, pp. 66-73.

GODWIN, R. J. 2015. Potential of "no-till" systems for arable farming. Report to the Worshipful Company of Farmers, 44 pp. Newport, Shropshire, U.K. : Soil and Water Management Centre, Harper Adams University. Retrieved from: https://cdn.harper-adams. ac.uk/document/project/Potential-of-No-till-Systems-for-ArableFarming-Report.pdf. Accessed 14 July 2015.

GODWIN, R. - MISIEWICZ, P. - WHITE, D. - SMITH, E. - CHAMEN, T. GALAMBOŠOVÁ, J. - STOBART, R. 2015. Results from recent traffic systems research and the implications for future work. In Acta Technologica Agriculturae, vol. 18, no. 3, pp. 57-63.

IMHOFF, S. C. 2015. Proyecto PIP: Tránsito controlado de la maquinaria: efecto sobre las propiedades del suelo y los cultivos en las zonas contiguas a las sendas de circulación. Personal communication. Esperanza, Argentina : Universidad Nacional del Litoral.

ISBISTER, B. - BLACKWELL, P. - RIETHMULLER, G. - DAVIES, S. WHITLOCK, A. - NEALE, T. 2013. Controlled traffic farming technical manual. WA, Australia : Northern Agricultural Catchments Council. Retrieved from: http://nacc.com.au/wp-content/uploads/2015/05/ NACC_Controlled_Traffic_Farming_Technical_Manual.pdf. Accessed 10 July 2015.

KASSAM, A. - FRIEDRICH, T. - SHAXSON, F. - PRETTY, J. 2009. The spread of conservation agriculture: justification, sustainability and uptake. In International Journal of Agricultural Sustainability, vol. 7, no. 4, pp. 292-320.

KELLER, T. - ARVIDSSON, J. 2004. Technical solutions to reduce the risk of subsoil compaction: effects of dual wheels, tandem wheels and tyre inflation pressure on stress propagation in soil. In Soil and Tillage Research, vol. 79, no. 2, pp. 191-205.

KELLER, T. - DÉFOSSEZ, P. - WEISSKOPF, P. - ARVIDSSON, J. RICHARD, G. 2007. SoilFlex: A model for prediction of soil stresses 
and soil compaction due to agricultural field traffic including a synthesis of analytical approaches. In Soil and Tillage Research, vol. 93, no. 2, pp. 391-411.

KINGWELL, R. - FUCHSBICHLER, A. 2011. The whole-farm benefits of controlled traffic farming: an Australian appraisal. In Agricultural Systems, vol. 104, no. 7, pp. 513-521.

KOOLEN, A. J. - LERINK, P. - KURSTJENS, D. A. G. - VAN DEN AKKER, J. J. H. - ARTS, W. B. M. 1992. Prediction of aspects of soil-wheel systems. In Soil and Tillage Research, vol. 24, pp. 381-396.

KROULÍK, M. - KUMHÁLA, F. - HU゚LA, J. - HONZÍK, I. 2009. The evaluation of agricultural machines field trafficking intensity for different soil tillage technologies. In Soil and Tillage Research, vol. 105, no. 1, pp. 171-175.

KUTZBACH, H. D. 2000. Trends in power and machinery. In Journal of Agricultural Engineering Research, vol. 76, no. 3, pp. 237-247.

LENCE, S. H. 2010. Chapter 14. The agricultural sector in Argentina: major trends and recent developments. In Alston, J. - Babcock, B. Pardey, P. (Eds). The Shifting Patterns of Agricultural Production and Productivity Worldwide. Ames, lowa : Midwest Agribusiness Trade and Research Information Center, lowa State University.

LI, Y. - TULLBERG, J. N. - FREEBAIRN, D. M. 2001. Traffic and residue cover effects on infiltration. In Soil Research, vol. 39, no. 2, pp. 239-247.

LI, Y. X. - TULLBERG, J. N. - FREEBAIRN, D. M. 2007. Wheel traffic and tillage effects on runoff and crop yield. In Soil and Tillage Research, vol. 97 , no. 2 , pp. 282-292.

LI, Y. X. - TULLBERG, J. N. - FREEBAIRN, D. M. - MCLAUGHLIN, N. B. - LI, H. W. 2008. Effects of tillage and traffic on crop production in dryland farming systems: II. Long-term simulation of crop production using the PERFECT model. In Soil and Tillage Research, vol. 100, no. 1-2, pp. 25-33.

LIPIEC, J. - STĘPNIEWSKI, W. 1995. Effects of soil compaction and tillage systems on uptake and losses of nutrients. In Soil and Tillage Research, vol. 35, no. 1-2, pp. 37-52.

LOGSDON, S. D. - ALLMARAS, R. R. - NELSON, W. W. - VOORHEES, W. B. 1992. Persistence of subsoil compaction from heavy axle loads. In Soil and Tillage Research, vol. 23, no. 1-2, pp. 95-110.

MANUEL-NAVARRETE, D. - GALLOPÍN, G. C. - BLANCO, M. - DÍAZZORITA, M. - FERRARO, D. O. - HERZER, H. - LATERRA, P. - MURMIS M. R. - PODESTÁ, G. P. - RABINOVICH, J. - SATORRE, E. H. - TORRES, F. - VIGLIZZO, E. F. 2009. Multi-causal and integrated assessment of sustainability: the case of agriculturization in the Argentine Pampas. In Environment, Development and Sustainability, vol. 11, no. 3, pp. 621-638.

MAŠEK, J. - KROULÍK, M. - CHYBA, J. - NOVÁK, P. - KUMHÁLA, F. 2014 Traffic intensity in fields and technical possibilities for reduction of machinery passes. In Engineering for Rural Development, vol. 13, pp. 216-220.

MCHUGH, A. D. - TULLBERG, J. N. - FREEBAIRN, D. M. 2009. Controlled traffic farming restores soil structure. In Soil and Tillage Research, vol. 104, no. 1, pp. 164-172.

McPHEE, J. E. - BRAUNACK, M. V. - GARSIDE, A. L. - REID, D. J. HILTON, D. J. 1995. Controlled traffic for irrigated double cropping in a semi-arid tropical environment: Part 1, Machinery requirements and modifications. In Journal of Agricultural Engineering Research, vol. 60, pp. 175-182.

McPHEE, J. E. - NEALE, T. - AIRD, P. L. 2013. Controlled traffic for vegetable production: Part 2. Layout considerations in a complex topography. In Biosystems Engineering, vol. 116, no. 2, pp. 171-178. MISIEWICZ, P. A. - BLACKBURN, K. - RICHARDS, T. E. - BRIGHTON, J. L. - GODWIN, R. J. 2015. The evaluation and calibration of pressure mapping system for the measurement of the pressure distribution of agricultural tyres. In Biosystems Engineering, vol. 130, pp. 81-91.
NEALE, T. 2011. The cost of grain harvester compaction. Precision Agriculture, Toowoomba, QLD, Australia. Retrieved from: http:// www.precisionagriculture.com.au/news-and-articles.php. Accessed 15 Nov 2014.

RADFORD, B. J. - YULE, D. F. - MCGARRY, D. - PLAYFORD, C. 2001. Crop responses to applied soil compaction and to compaction repair treatments. In Soil and Tillage Research, vol. 61, pp. 157-166. RADFORD, B. J. - YULE, D. F. - MCGARRY, D. - PLAYFORD, C. 2007. Amelioration of soil compaction can take 5 years on a Vertisol under no till in the semi-arid subtropics. In Soil and Tillage Research, vol. 97, no. 2, pp. 249-255.

RATAJ, V. - GALAMBOŠOVÁ, J. - VAŠEK, M. 2013. Determining the guidance system accuracy with the support of a large GNSS dataset. In Research in Agricultural Engineering, vol. 59, pp. S65-S70.

RUSER, R. - FLESSA, H. - RUSSOW, R. - SCHMIDT, G. - BUEGGER, F. MUNCH, J. C. 2006. Emission of $\mathrm{N}_{2} \mathrm{O}, \mathrm{N}_{2}$ and $\mathrm{CO}_{2}$ from soil fertilized with nitrate: effect of compaction, soil moisture and rewetting. In Soil Biology Biochemistry, vol. 38, no. 2, pp. 263-274.

SADS. 2015. Secretaria de Ambiente y Desarrollo Sustentable de la Nacion (2015): Programa de Acción Nacional de Lucha Contra la Desertificación-PAN. Sección 5.4: Ley No. 22.428 de Fomento a la Conservación de Suelos. Retrieved from: http://www.ambiente. gob.ar/?idarticulo=610. Accessed 30 June 2015.

SIIA. 2015. Sistema Integrado de Información Agropecuaria (2015): Series temporales. Ministerio de Agricultura, Ganadería y Pesca de la República Argentina. Retrieved from: http://www.siia.gov.ar/ series. Accessed 30 June 2015.

SMITH, E. K. - MISIEWICZ, P. A. - GIRARDELLO, V. - ARSLAN, S. CHANEY, K. - WHITE, D. R. - GODWIN, R. J. 2014. Effects of traffic and tillage on crop yield (winter wheat, Triticum aestivum L.) and the physical properties of a sandy loam soil. ASABE Paper No. 141912652. St. Joseph, Mich. : ASABE.

SOANE, B. D. - VAN OUWERKERK, C. 1995. Implications of soil compaction in crop production for the quality of the environment. In Soil and Tillage Research, vol. 35, no. 1-2, pp. 5-22.

SPOOR, G. - TIJINK, F. G. J. - WEISSKOPF, P. 2003. Subsoil compaction: risk, avoidance, identification and alleviation. In Soil and Tillage Research, vol. 73, no. 1-2, pp. 175-182.

TITMARSH, G. - WATERS, D. - WILSON, A. - WOCKNER, G. - BURGIS, M. - CONNOLLY, R. 2003. Experiences in runoff and erosion of controlled traffic farming systems, southern Queensland. In Proc. $16^{\text {th }}$ Triennial Conf., International Soil and Tillage Research Organisation. Brisbane, Australia : ISTRO, pp. 1235-1240.

TULLBERG, J. 2010. Tillage, traffic and sustainability - A challenge for ISTRO. In Soil and Tillage Research, vol. 111, no. 1, pp. 26-32.

TULLBERG, J. - MCHUGH, A. D. - KHABBAZ, B. G. - SCHEER, C. GRACE P. 2011. Controlled traffic/permanent bed farming reduces GHG emissions. In Proc. $5^{\text {th }}$ World Congress of Conservation Agriculture 2011: Resilient Food Systems for a Changing World. Canberra, Australia : Australian Centre for International Agricultural Research.

TULLBERG, J. N. 2000. Wheel traffic effects on tillage draught. In Journal of Agricultural Engineering Research, vol. 75, no. 4, pp. 375-382.

TULLBERG, J. N. - YULE, D. F. - MCGARRY, D. 2007. Controlled traffic farming - From research to adoption in Australia. In Soil and Tillage Research, vol. 97, no. 2, pp. 272-281.

TULLBERG, J. N. - ZIEBARTH, P. J. - LI, Y. X. 2001. Tillage and traffic effects on runoff. In Soil Research, vol. 39, no. 2, pp. 249-257. 